\title{
Microbiological Study of Raw Milk Collected from Local Milk Vendors of Lucknow District, UP, India
}

\author{
Amit Kumar Singh and Uma Shankar* \\ Department of Microbiology/Life Sciences, Singhania University, Rajasthan, India \\ *Corresponding author
}

\author{
A B S T R A C T
}

\begin{tabular}{|l}
\hline K e y w o r d s \\
Raw milk, \\
Physicochemical \\
parameters, Milk, \\
Coliform count. \\
\hline Article Info \\
\hline $\begin{array}{l}\text { Accepted: } \\
\text { 26 March } 2017 \\
\text { Available Online: } \\
\text { 10 May } 2017\end{array}$ \\
\hline
\end{tabular}

\section{Keywords}

Raw milk, ysicochemical Coliform count.

\section{Introduction}

India is the world largest producer of milk. Milk production in India is projected to be between 180-200 million tones by 2021-22 and the production of milk is expected to increase at the rate of 5\% per annum (Parekh, 2011). Milk is a white liquid produced by the mammary glands of mammals. It is the primary source of nutrition for young mammals before they are able to digest other types of food. Early lactation milk contains colostrum, Milk contains various types of bacteria and as it is said that there are two sides of a coin in the same manner milk have both good and harmful bacteria constitution. Milk from cows, sheep and goats is rich in microorganisms. Lactic acid bacteria, the most abundant microorganisms found in milk, facilitate dairy fermentation and promote health. As per the guide lines of International Dairy Federation the production of milk having Standard Plate Count of $104 \mathrm{Cfu} / \mathrm{ml}$ reflects good hygienic practices while high initial Standard Plate Count of more than 105 $\mathrm{Cfu} / \mathrm{ml}$ are evidence of serious faults in production hygiene (IDF, 1990). In Lucknow city thirty five thousand liters of raw milk is sold by milk vendors and milk vending shops. Raw unpackaged and unprocessed milk sold is much below standards in hygiene; their bacteriological quality needs to be rigorously monitored with regard to both number and type of micro flora present. 


\section{Materials and Methods}

The present area of investigation, district Lucknow were originally loads milk vending shops in and around the district. The district Lucknow is located at Latitude $27.57^{\circ} \mathrm{N}$ and $80.68^{\circ} \mathrm{E}$. It is located on the Gangestics plains with elevations ranging from 150 meter above sea level in the north and in the North West to 100 meter. The Lucknow City is situated on the bank of river Gomti, Half way between Sitapur and Barabanki on the Faizabad-Delhi National Highway No.24 and $89 \mathrm{Km}$. North west from the district is Barabanki. Lucknow district is surrounded by district Kheri in the North, District Sitapur in the East, district Uannao in the South, District Barabanki in the south east and district Hardoi in the west. The geographical area of Lucknow district is 5743 Sq. Km

\section{Collection of samples}

In this study sample of raw milk was collected randomly by selecting the shops and residential area from the different zones of Lucknow city. A total of 05 samples in triplicate from local vendors (those delivering milk on vehicles) and milk vending shops of each zone was collected for raw milk. Multiple sampling was also done. Each sample was of $200 \mathrm{ml}$. for raw milk. These samples were collected for two consecutive years, January 2015 to December 2016.

Samples of raw milk were collected in sterile glass bottles after proper mixing. Each sample container was sealed air tight after filling with sample. Containers were marked with source of sample, the date and time of sampling and other relevant information. After collection the samples were cooled and carried in ice box maintaining at a temperature of $4-50 \mathrm{C}$ and brought to the laboratory. They were preserved in refrigerators until analyzed.

\section{Physico-chemical parameters}

Parameters analyzed in this study are Temperature, $\mathrm{pH}$, Titrable acidity, Density and conductivity for the samples of raw milk as per the methods of AOAC3. Conductivity was measured by electro conductivity cell (Systronic, 304) according to the manufactures instruction. Prior to use it is calibrated using potassium chloride $(\mathrm{KCl})$ reference solution. $\mathrm{pH}$ value of milk was determined by using a digital $\mathrm{pH}$ meter (Labatronics EI). Bacteriological parametersSamples of raw milk were examined for their Standard plate counts and Coliform counts (Andrews, 1992; APHA, 1992). Ten fold serial dilutions of samples were made upto 10-8 in phosphate buffer. Triplicates of samples were plated using pour plate technique on Plate Count Agar Media (Himedia, M091) for Standard plate count and Violet Red Bile Agar (Hi media, M049) for Coliform count, petri plates were thoroughly mixed and allow to solidify then plates were incubated in inverted position at $37^{0 \mathrm{C}}$ for 24 hrs after incubation plates containing colonies between $30-300$ were counted and results were expressed as $\mathrm{Cfu} / \mathrm{ml}$.

\section{Statistical analysis}

Number of bacteria present in $1 \mathrm{ml}$ of samples was calculated as per the formula (Maturin and Peeler, 2001; Tassew and Seifu, 2011). All microbial counts were changed to the $\log 10$ of the number of colony forming units per $\mathrm{ml}(\log 10 \mathrm{Cfu} / \mathrm{ml})$ and from these Maximum, Minimum, Mean values and their Standard error were calculated. Data were analyzed using Analysis of Variance (ANOVA) and mean variation were compared by using Fisher's Least Square Deviation (LSD) to further interpret the results at 5\% and $1 \%$ significance level by software (SYSTAT Version 13, 2011). 


\section{Results and Discussion}

The findings of the present study are in concurrence with their findings. Coliform bacteria are associated with fecal and environmental contamination. Mean annual Coliform counts for the samples of raw milk collected from milk vendors were ranged between 3.20 to 4.23 with a mean of $3.86 \pm$ $0.1165 \log 10 \mathrm{cfu} / \mathrm{ml}$ in the year 2015 , where as it ranges from 3.46 to 4.97 with a mean of $4.16 \pm 0.1660 \log 10 \mathrm{Cfu} / \mathrm{ml}$ in the year 2016 . The overall mean Coliform count of samples for both the year shows minimum 3.33 and maximum 4.65 with a mean of $4.01 \pm 0.1413$ $\log 10 \mathrm{Cfu} / \mathrm{ml}$. In the case of milk vending shops Coliform count ranged from 3.36 to 5.36 with a mean of $4.27 \pm 0.1761 \log 10$ $\mathrm{Cfu} / \mathrm{ml}$ in the year 2015. Coliform counts for year 2016 varied from 3.55 to 5.42 with a mean of $4.44 \pm 0.1839 \log 10 \mathrm{Cfu} / \mathrm{ml}$. Average Coliform count of milk samples for both the years shows maximum 5.39 and minimum 3.46 with a mean of $4.36 \pm 0.180 \log 10 \mathrm{Cfu} /$ $\mathrm{ml}$. results of Statistical analysis of the Coliform counts also revealed significant. The difference between counts of milk samples from both sources. Coliform counts obtained in this study were higher than reported earlier. This is an indicator of unsanitary conditions or practices during production processing and distribution or storage of raw milk. Inadequate cooling of milk and udder infections was also responsible for these higher counts (Table 1, Fig. 2).

Mankind has been respecting milk as divine drop of health since the dawn of civilization. It is considered as an excellent culture medium for multiplication of several bacteria. They grow and multiply in milk and causes chemical changes that make it unpalatable. Quality of the raw milk can be judged by microbial load. Coliforms bacteria are a commonly used bacterial indicator of sanitary quality of foods and water. They are defined as rod-shaped Gram-negative non-spore forming and motile or non-motile bacteria which can ferment lactose with the production of acid and gas when incubated at $35-37^{\circ} \mathrm{C}$. Coliform bacteria are a commonly used bacterial indicator of sanitary quality of foods and water. They are defined as rod-shaped Gram-negative non-spore forming and motile or non-motile bacteria which can ferment lactose with the production of acid and gas when incubated at $35-37^{\circ} \mathrm{C}$ (Fig. 1). Coliforms can be found in the aquatic environment, in soil and on vegetation; they are universally present in large numbers in the feces of warm-blooded animals. While coliforms themselves are not normally causes of serious illness, they are easy to culture, and their presence is used to indicate that other pathogenic organisms of fecal origin may be present. Such pathogens include diseasecausing bacteria, viruses, or protozoa and many multicellular parasites. Coliform procedures are performed in aerobic or anaerobic conditions. Coliforms are destroyed during pasteurization. Typical genera include Escherichia. Escherichia coli (E. coli), a rodshaped member of the coliform group, can be distinguished from most other coliforms by its ability to ferment lactose at $44^{\circ} \mathrm{C}$ in the fecal coliformtest, and by its growth and color reaction on certain types of culture media. When cultured on an eosin methylene blue (EMB) plate, a positive result for E. coli is metallic green colonies on a dark purple media. Escherichia coli have an incubation period of 12-72 hours with the optimal growth temperature being $30-37^{\circ} \mathrm{C}$. Unlike the general coliform group, E. coli are almost exclusively of fecal origin and their presence is thus an effective confirmation of fecal contamination. Most strains of E. coli are harmless, but some can cause serious illness in humans. Infection symptoms and signs include bloody diarrhea, stomach cramps, vomiting and occasionally, fever. The bacteria can also cause pneumonia, other respiratory illnesses and urinary tract infections. 
Mean annual temperature of samples collected from milk vendors ranged between $14.4^{\circ} \mathrm{C}$ to $22.3^{\circ} \mathrm{C}$ with a mean of $17.18^{\circ} \mathrm{C} \pm$ 0.1320 , for milk vending shops it varied from $12.6^{\circ} \mathrm{C}$ to $21.4^{\circ} \mathrm{C}$ with a mean of $19.03^{\circ} \mathrm{C} \pm$ 0.4315 . The mean temperature recorded from both sources (MV+MVS) in this study was almost similar $\left(19^{\circ} \mathrm{C}\right)$, which is favorable for the growth of bacteria. Some variations in the mean temperature were recorded that depended on environmental fluctuations. Such an higher recorded temperature were indicative of lack of proper cooling during storage and distribution of raw milk samples and indicative of higher count of bacteria as recorded in different countries like Iran and Kenya (Shojaei and Yadollah, 2008; Mwangi, 2000).

$\mathrm{pH}$ of samples collected from milk vendors were in the range of 4.8 to 7.0 for milk vending shops it ranged between 5.6 to 6.7 (Fig. 3). pH of the milk samples is related to acidity. Lower $\mathrm{pH}$ is indicative of higher developed acidities due to action of microbes where as higher $\mathrm{pH}$ values were obtained when cattle's were suffering from Mastitis 10 , 11. In other studies various range of $\mathrm{pH}$ readings such as 6.44 - 6.99 have been reported (Kanwal et al., 2002). Titrable acidity is a sum of natural and developed acidity and is an indication of quality of raw milk. According to Indian Standard the natural acidity of raw milk is $0.13 \%$ to $0.15 \%$ lactic acid14. Titrable acidity for the samples of raw milk collected from milk vendors ranged between $0.142-0.231 \%$ with a mean of $0.183 \pm 0.0044 \%$.

In case of milk vending shops it ranges from 0.150 to $0.220 \%$ with a mean of $0.181 \pm$ $0.0033 \%$ lactic acid. The difference in acidity was metabolic activities of microbes. Longer period of storage is also responsible for higher Titrable acidity which in turn affects bacteriological quality of raw milk samples.

Conductivity is the ability of ionic matter to carry electric current. Conductivity of raw milk samples collected from milk vendors varied from $3.29-3.48 \mathrm{mS} / \mathrm{cm}$ with a mean of $3.39 \pm 0.0090 \mathrm{mS} / \mathrm{cm}$. In the case milk vending shops it varied from 3.18 to $4.32 \mathrm{mS} / \mathrm{cm}$ with a mean of $3.64 \pm 0.0600 \mathrm{mS} / \mathrm{cm}$. Mabrook and Petty studied the effect of milk composition on its electrical conductance they have reported that the mineral salts dissociated in the aqueous of milk played the dominant role in controlling this property; they have also reported that the conductance is affected by milk fat. The samples of raw milk in the present study have exhibited lower conductivities. Such lower conductivities 2.74 to $4.3 \mathrm{mS} / \mathrm{cm}$ for raw milk samples were also reported in Morocco.

Fig.1 A plate of coliforms present in milk

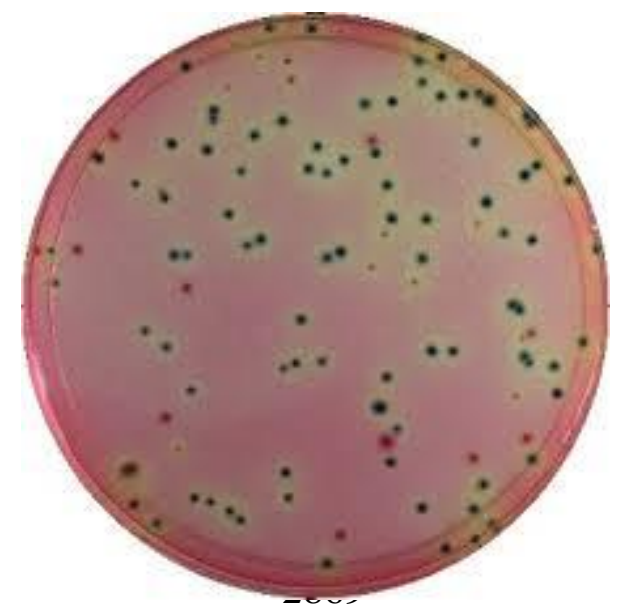


Fig.2 Growth of coliforms in VRBA media

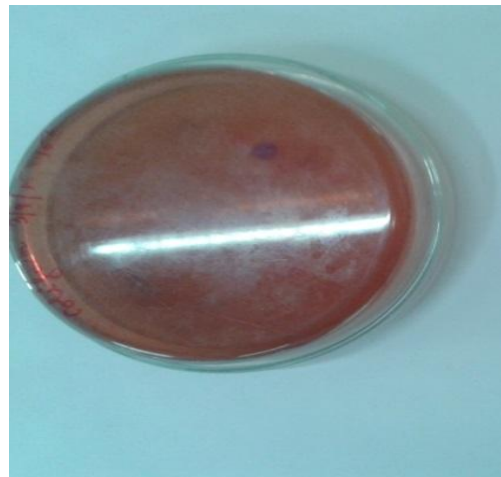

Sample 1

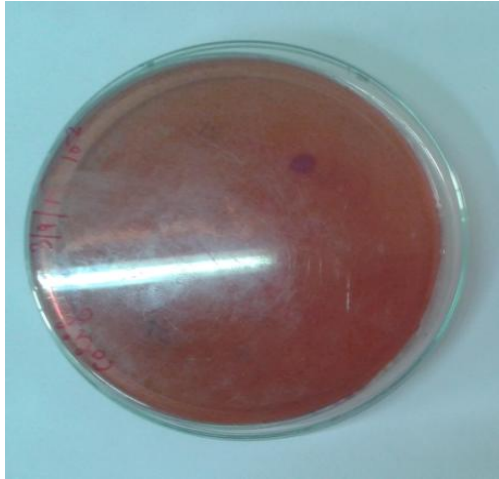

Sample 3

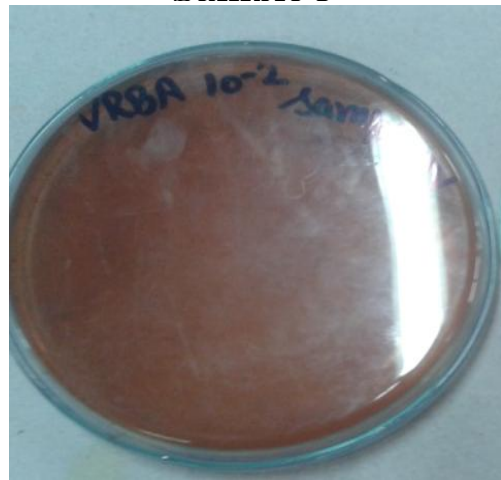

Sample 5

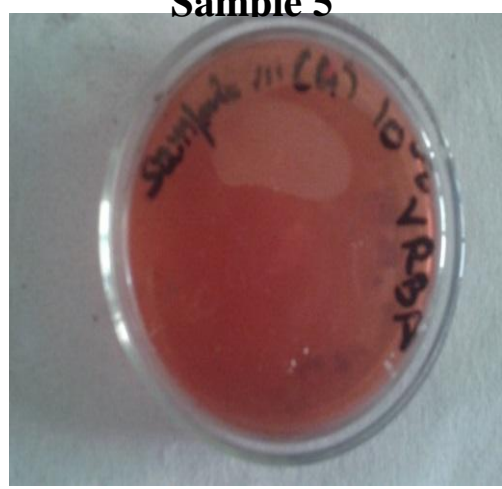

Sample 7

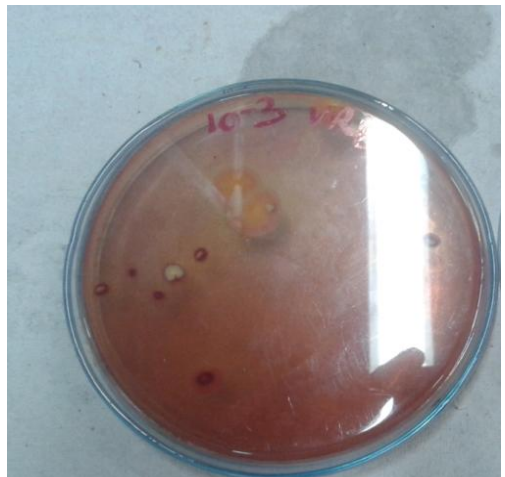

Samble 2

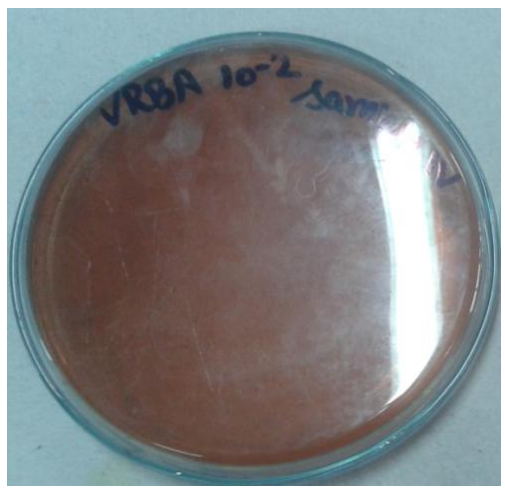

Samble 4

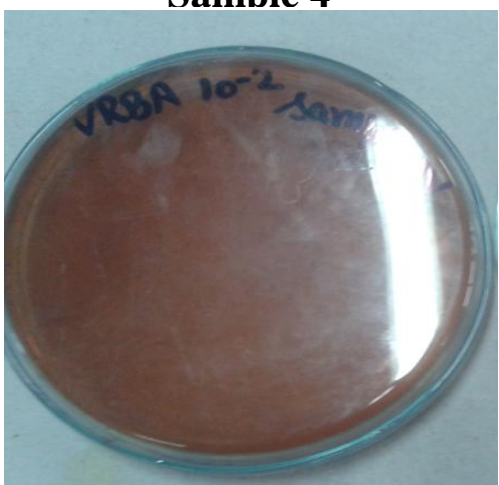

Sample 6

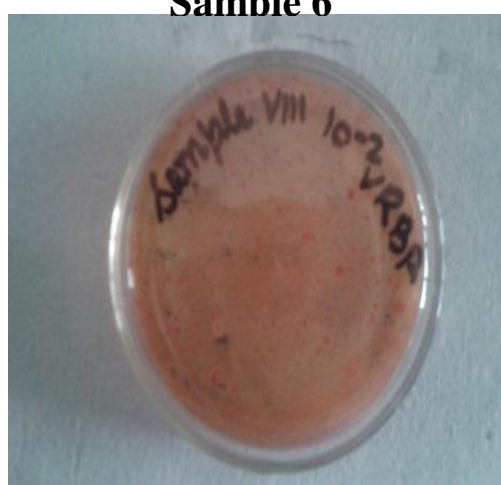

Sample 8 
Fig.3 pH of milk samples

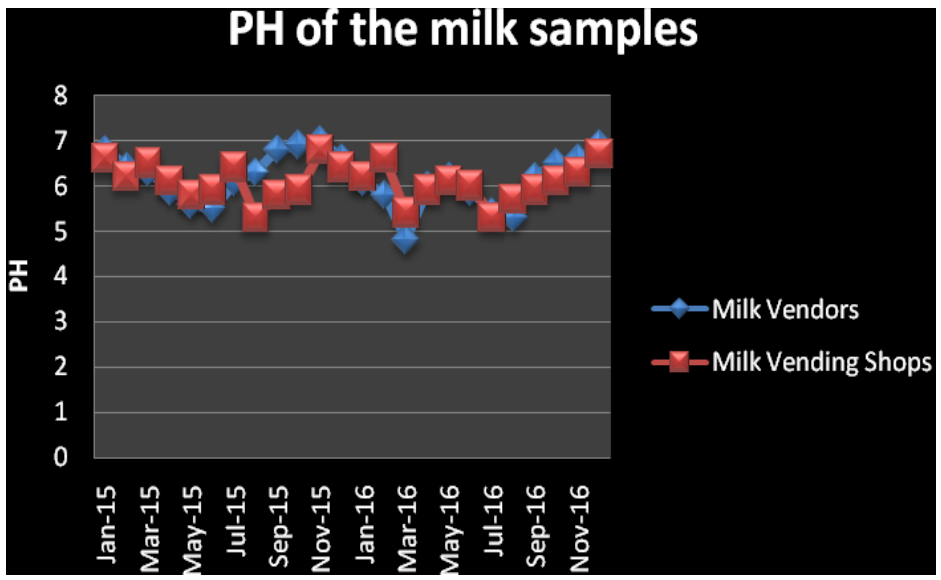

Table.1 In VRBA media growth of coliforms were observed

\begin{tabular}{|c|c|c|c|c|}
\hline $\begin{array}{c}\text { Sample } \\
\text { number }\end{array}$ & $\begin{array}{c}\text { Number of } \\
\text { bacterial } \\
\text { colonies }\end{array}$ & $\begin{array}{c}\text { Dilution } \\
\text { factor }\end{array}$ & $\begin{array}{c}\text { Total number } \\
\text { of bacteria }\end{array}$ & $\begin{array}{c}\text { Colour of } \\
\text { colonies }\end{array}$ \\
\hline 1 & 1 & 100 & 100 & Pink \\
\hline 2 & 7 & 1000 & 7000 & Pink \\
\hline 3 & 1 & 100 & 100 & Pink \\
\hline 4 & none & none & none & None \\
\hline 5 & none & none & none & None \\
\hline 6 & none & none & none & None \\
\hline 7 & none & none & none & None \\
\hline 8 & 210 & 100 & 21000 & Pink \\
\hline
\end{tabular}

Bacteriological quality of raw milk and milk products was assured by Standard plate count method The overall standard plate count of raw milk samples collected from vendors for two consecutive years shows minimum 5.13 and maximum 7.26 with a mean of $6.13 \pm 0$. $083 \log 10 \mathrm{Cfu} / \mathrm{ml}$. In case of milk vending shops average standard plate count of raw milk samples for two consecutive years shows minimum 5.60 and maximum 7.50 with a mean of $6.37 \pm 0.085 \log 10 \mathrm{Cfu} / \mathrm{ml}$.

Results of Analysis of Variance test of the data revealed that there is highly significant set by BIS for raw milk. Some workers reported these counts with a mean of
$5.50 \pm 0.99 \log 10 \mathrm{Cfu} / \mathrm{ml}$ from raw milk samples collected from vendors of Faizabad district of Uttar Pradesh (Chandrasekhar, 2002). The findings of the present study are in concurrence with their findings. Coliform bacteria are associated with fecal and environmental contamination. Mean annual Coliform counts for the samples of raw milk collected from milk vendors were ranged between 3.20 to 4.23 with a mean of $3.86 \pm$ $0.1165 \log 10 \mathrm{cfu} / \mathrm{ml}$ in the year 2015 , where as it ranges from 3.46 to 4.97 with a mean of $4.16 \pm 0.1660 \log 10 \mathrm{Cfu} / \mathrm{ml}$ in the year 2016 . The overall mean Coliform count of samples for both the year shows minimum 3.33 and maximum 4.65 with a mean of $4.01 \pm 0.1413$ 
$\log 10 \mathrm{Cfu} / \mathrm{ml}$. In the case of milk vending shops Coliform count ranged from 3.36 to 5.36 with a mean of $4.27 \pm 0.1761 \log 10$ $\mathrm{Cfu} / \mathrm{ml}$ in the year 2015. Coliform counts for year 2016 varied from 3.55 to 5.42 with a mean of $4.44 \pm 0.1839 \log 10 \mathrm{Cfu} / \mathrm{ml}$. Average Coliform count of milk samples for both the years shows maximum 5.39 and minimum 3.46 with a mean of $4.36 \pm 0.180 \log 10 \mathrm{Cfu} /$ $\mathrm{ml}$. results of Statistical analysis of the Coliform counts also revealed significant. The difference between counts of milk samples from both sources. Coliform counts obtained in this study were higher than reported earlier. This is an indicator of unsanitary conditions or practices during production processing and distribution or storage of raw milk. Inadequate cooling of milk and udder infections was also responsible for these higher counts.

In conclusion, the present study reveals that the quality of raw milk in Lucknow city was not satisfactory. It is confirmed by the high values of total bacterial count, Coliform counts and physico-chemical tests. Presence of such higher counts causes deterioration in the quality of raw milk. In conclusion, it can be said that the raw milk sold in the study area may pose a potential public health risk and therefore, hygienic precautions should be taken by determining critical control points from phases of production, storage and sale.

\section{References}

AOAC, Dairy products, In: Official Method of Analysis. The Association of Official Analytical Chemists, 16 Th Editions 481 North Fredrick Avenue Gaitherburg, Maryland, U.S.A (2005) 4. Andrews D., Manual of food quality control: microbiological analysis.

APHA, In Compendium Methods for the Microbial Examination of Foods, Downes, F. P. and K. Ito (Eds.), 4 th
Edn,, American Public Health Association, Washington D.C., 63-68, 159-164 (1992)

Chandrasekhar E. Motinia and Sunil Kumar, Microbiological quality of raw milk and its public health significance, Journal Dairying Foods and H.S., 29(1), 15-18 (2010)

IDF, International Dairy Federation, Milk collection in warm developing countries, Squire Verboten Brussels, Belgium, 57-59 (1990)

Kanwal R., Ahmed T. and Mirza B., Comparative analysis of quality of milk collected from Rawalpindi / Islamabad region (Pakistan), Pak. J. Food Sci., 12, 29-33 (2002)

Kurt A., Cakmakci S. and Caylar S., Guide of inspection and analysis method in Milk and Milk product, Agricultural Faculty Press, E. Rzurum, 284 (2003)

Maturin L.J. and Peeler J.T., Bacteriological analytical manual online, U.S. Food and Drug Administration, Chapter-3, Aerobic plate count (2001).

Mennane Z., Ouhssine M., Khedid K. and Elyachioui M., Hygienic quality of raw cow milk feeding from domestic waste in two regions in Morocco, Int. J. Agriculture and Biology, 9 (1), 4648 (2007)

Mwangi A., Arimi S.M., Mbugua S., Kangethe E.K. and Omore A.O., Assurance of marketed milk quality in Kenya, Paper presented at the Faculty of Veterinary Medicine Biennial Scientific Conference, 30-31 Aug. University of Nairobi., Kenya (2000)

Ozrenk E. and Selcuk I.S., The effect of seasonal variation on the composition of cow milk in Van province, Pak. J. Nutr., 7, 161-164 (2008)

Parekh J.V., Sustainable profitable dairying through innovation, In Souvenir, National seminar on paradigm shift in Indian dairy industry held at SMC 
College of Dairy Science, Anand agricultural university, Anand., May, 21-22, 14-20 (2011)

Revision-1, Food and Agriculture Organization of the United Nations Pub., Rome (1992)

Shojaei Z.A., and Yadollahi A., Physico chemical and Microbiological Quality of Raw, Pasteurized and UHT milk in shops, Asian. J. of Sci. Research, 1(5), 532-538 (2008)

Tassew A. and SeifuE., Microbiological quality of raw cow's milk collected from farmers and dairy cooperatives in Bahir Dar Zuria and Mecca district, Ethiopia, Agric. Biol. J. Nu. Am., 2(1), 29 -33 (2011)

Walstra P., Wouters J.T.M and Geurts I.J., Dairy Science and Technology, 2 nd Ed., CRC Press, Taylor and Francis group, Boca Raton (2006)

Yadav J.S, Grover S. and Batish V.K., Comprehensive Dairy Microbiological I ST Edition metropolitan Book Co. Pvt. Ltd, New Delhi, 210 -214 (1993)

\section{How to cite this article:}

Amit Kumar Singh and Uma Shankar. 2017. Microbiological Study of Raw Milk Collected from Local Milk Vendors of Lucknow District, UP, India. Int.J.Curr.Microbiol.App.Sci. 6(5): 2866-2873. doi: https://doi.org/10.20546/ijcmas.2017.605.325 